\title{
PERFUSION STUDIES OF THE HUMAN PLACENTA. I. EFFECT OF ESTRADIOL AND HUMAN CHORIONIC GONADOTROPIN ON CITRIC ACID METABOLISM 1,2
}

\author{
BY PHILIP TROEN AND EDWIN E. GORDON \\ (From the Department of Medicine, Harvard Medical School, and the Medical Research De- \\ partment of the Yamins Research Laboratories, Beth Israel Hospital, Boston, Mass.)
}

(Submitted for publication April 15, 1958; accepted July 17, 1958)

The varied endocrine changes during human pregnancy have been intensively studied (1). The significant role of the placenta in these changes is evident from its demonstrated production of chorionic gonadotropin (2), estrogens (3) and progesterone (4). In addition, the demonstration of other hormones [corticosteroids $(5,6)$, corticotropin (7-9), androgens (10), relaxin (11), aldosterone (12)] in extracts of placental tissue has suggested still further endocrine functions of the placenta. However, three broad -areas remain unclarified: a) What hormones are produced by the placenta, $b$ ) what are the metabolic pathways for such hormone production, and $c$ ) what is the interaction of placental hormones with maternal and fetal hormones and their joint contribution to the metabolic changes of pregnancy. Such basic information may have direct application to hormonal metabolism unassociated with pregnancy and also may be of clinical value in the management of disorders of pregnancy.

Organ perfusion has been a rewarding approach to the study of the metabolic functions of endocrine glands, as exemplified by the studies of Hechter and co-workers (13) with perfusion of beef adrenal glands. The extension of this general technique to the human placenta seemed to offer a promising approach to the solution of the problems outlined above. Perfusion of the whole placenta appears to be a more nearly physiologic approach to metabolic and synthetic activities of the placenta than does the study of homogenates, slices and perfused isolated cotyledons. Accordingly, we have undertaken a study of the perfusion of

\footnotetext{
1 Supported by grants from the Milton Fund of Harvard University, the United States Public Health Service (RG-4802), and the Massachusetts Heart Association.

2 A preliminary abstract was published in The Journal of Clinical Investigation, 1957, 36, 932.
}

whole human placentas obtained immediately after full term delivery.

The normal full term placenta presents histologic (14) and metabolic (15) evidence of senescence. Therefore, it was important to demonstrate evidence of metabolic activity of the term placenta under the conditions of perfusion. Villee and Hagerman (16) have demonstrated the functional activity of enzymes of the citric acid cycle in homogenates of human term placenta; accordingly citrate utilization and alpha-ketoglutarate production by the perfused placenta were selected as parameters of continuing placental metabolic activity. The purpose of this paper is twofold: 1) to report that metabolic activity of the intact term placenta persists for at least nine hours after delivery under our conditions of perfusion and 2) to report the effect on this metabolic activity of addition of hormones to the perfusion fluid. A new action of human chorionic gonadotropin is described.

\section{MATERIALS AND METHODS}

Human placentas from normal term pregnancies were obtained two to seven minutes after vaginal delivery of the infant. The placentas were immersed in ice cold physiologic saline solution for transport to the laboratory. There the membranes were removed, the surfaces of the placenta were washed free of clots, and the organ was weighed. In preparation for the perfusion, the umbilical vein was catheterized and the larger arteries of the fetal surface of the placenta were incised. The organ was then placed in the perfusion system. The time from delivery of the baby to the beginning of perfusion did not exceed 30 minutes. The perfusion apparatus was similar to that described by Young, Prudden and Stirman (17) for liver perfusion, except that direct pulsatile perfusion was obtained by removal of the hydrostatic reservoir. The pressure as recorded proximal to the catheter averaged 220 over $80 \mathrm{~mm}$. mercury.

The standard perfusing solution had the following composition in millimoles per liter: $\mathrm{NaCl}, 129.5 ; \mathrm{KCl}$, $2.7 ; \mathrm{CaCl}_{2}, 1.8 ; \mathrm{MgCl}_{2}, 0.5, \mathrm{NaH}_{2} \mathrm{PO}_{4}, 0.5 ; \mathrm{NaHCO}_{3}$, 11.9; and citric acid, 5.0. To each liter of perfusing fluid 


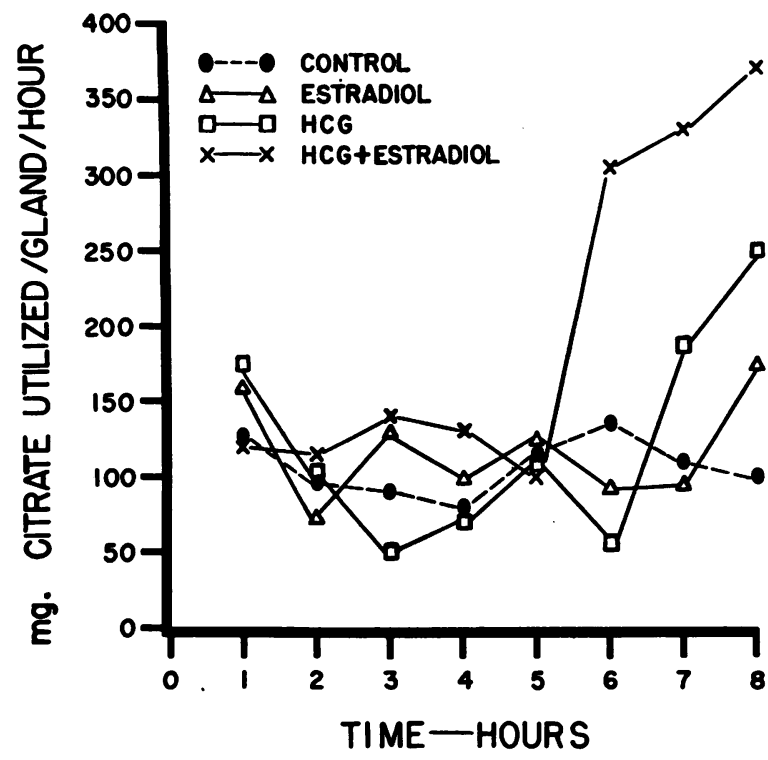

Fig. 1. The Utilization of Citrate by Human PlaCentas Perfused with ANd without Added Hormones Each curve is the average of three perfusions.

were added 100,000 units of crystalline penicillin and 1.0 gram of streptomycin. In some experiments hormones were added to the standard perfusing fluid: estradiol-17 beta dissolved in $4 \mathrm{ml}$. of propylene glycol for a final concentration of $3.57 \times 10^{-2}$ millimoles per liter of perfusing fluid; human chorionic gonadotropin $(\mathrm{HCG})^{\mathbf{3}}$ dissolved in water for a final concentration of 20,000 International Units per liter. The perfusion fluid was passed down a Vigreux column through an atmosphere of 95 per cent oxygen and 5 per cent carbon dioxide. The $\mathrm{pH}$ was maintained at 7.4 and the temperature at 37 to $38^{\circ} \mathrm{C}$.

An initial 20 minute perfusion was performed with one liter of standard solution to remove blood from the vascular spaces and to bring the placenta to the desired temperature. This perfusate was discarded and the system recharged with a liter of fresh perfusing fluid. Thereafter, at hourly intervals the system was drained of fluid and recharged with a liter of fresh fluid. The perfusate was recycled at an average rate of flow of 150 to $200 \mathrm{ml}$. per minute. Perfusions were carried out for eight hours. Changes in perfusing fluid volume and placenta weight were noted after each hourly run. Ten $\mathrm{ml}$. aliquots of perfusate were removed for assay from the system five minutes after the start and again at the completion of each run. The aliquots were frozen and kept at -10 to $-20^{\circ} \mathrm{C}$. until analyzed. Citrate was determined by the method of Natelson, Pincus and Lugovoy (18) and total alpha-keto acids (calculated as alphaketo glutaric acid) by the method of Friedemann and Haugen (19). Analyses were done in duplicate. Com-

${ }^{8}$ Generously supplied by Ayerst Laboratories through the courtesy of Dr. John B. Jewell.

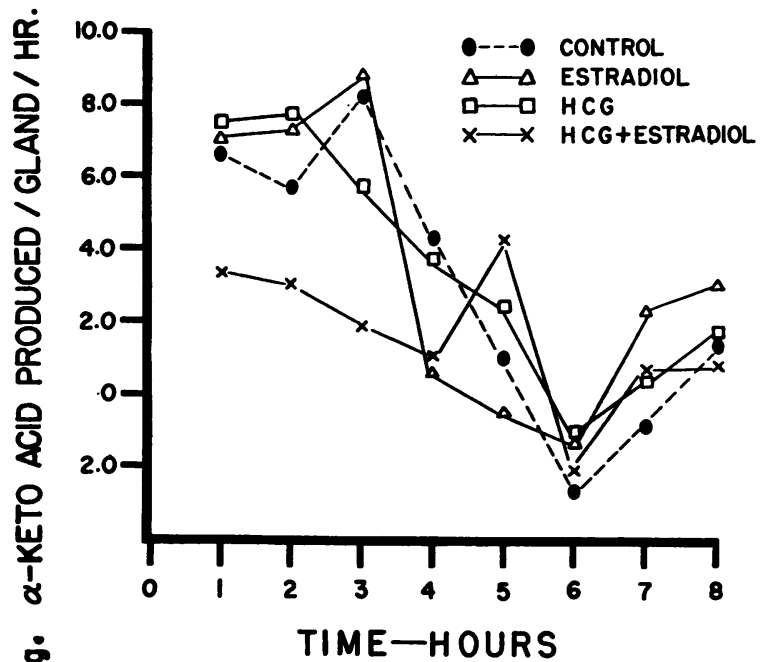

Fig. 2. The Production of Alpha-Keto Acid (Measured as Alpha-Keto Glutarate) by Human Placentas Perfused with and without Added HORMONES

Each curve is the average of three perfusions.

parison of analyses of fresh samples with those stored in the frozen state showed no significant change. The hourly change in circulating citrate and alpha-keto acid was determined from the difference between the amounts circulating five minutes after the start of the run and at the end of the hour.

\section{RESULTS}

The effect of addition of hormones to the perfusing fluid was studied in four groups of three placentas each: 1) standard solution, 2) added estradiol, 3) added HCG, and 4) added estradiol plus HCG. Figure 1 indicates the hourly citrate utilization for each treatment group. Figure 2 indicates the hourly production of alpha-keto acid. Each curve is plotted from the means of results from three placental perfusions. The observed values are included in Tables I and II. Since the residual error term for each measurement was of similar magnitude in the different treatments, ${ }^{4}$ combined analyses of the citrate and alpha-keto acid values, respectively, were done by the splitplot method (21). Major portions of the analysis are presented in Table III. To test the significance of differences between mean values for each treatment the mean square error term of line 2 of

4 Bartlett's test for heterogeneity of variance (20) gave p $>0.30$ in each instance. 
TABLE I

Citrate utilization (mg. per gland) *

\begin{tabular}{|c|c|c|c|c|c|c|c|c|c|c|c|c|}
\hline \multirow{2}{*}{$\begin{array}{c}\text { Expt. } \\
\text { no. }\end{array}$} & \multirow[b]{2}{*}{ Treatment } & & \multirow{2}{*}{$\begin{array}{c}\text { Gland } \\
\text { weight } \\
\text { (grams) }\end{array}$} & \multicolumn{8}{|c|}{ Hour } & \multirow[b]{2}{*}{ Mean } \\
\hline & & & & 1 & 2 & 3 & 4 & 5 & 6 & 7 & 8 & \\
\hline \multirow[t]{2}{*}{$\begin{array}{l}1 \\
2 \\
3\end{array}$} & $\begin{array}{l}\text { Control } \\
\text { Control } \\
\text { Control }\end{array}$ & & $\begin{array}{l}639 \\
474 \\
539\end{array}$ & $\begin{array}{r}96 \\
174 \\
106\end{array}$ & $\begin{array}{r}80 \\
103 \\
110\end{array}$ & $\begin{array}{r}10 \\
105 \\
152\end{array}$ & $\begin{array}{r}129 \\
70 \\
43\end{array}$ & $\begin{array}{r}154 \\
99 \\
90\end{array}$ & $\begin{array}{r}165 \\
244 \\
0\end{array}$ & $\begin{array}{r}111 \\
91 \\
131\end{array}$ & $\begin{array}{r}17 \\
218 \\
66\end{array}$ & $\begin{array}{r}95 \\
138 \\
87\end{array}$ \\
\hline & & Mean & 564 & 125 & 98 & 89 & 81 & 114 & 136 & 111 & 100 & 107 \\
\hline \multirow[t]{2}{*}{$\begin{array}{l}4 \\
5 \\
6\end{array}$} & $\begin{array}{l}\text { Estradiol } \\
\text { Estradiol } \\
\text { Estradiol }\end{array}$ & & $\begin{array}{l}514 \\
624 \\
410\end{array}$ & $\begin{array}{r}91 \\
103 \\
290\end{array}$ & $\begin{array}{r}114 \\
31 \\
75\end{array}$ & $\begin{array}{r}141 \\
158 \\
89\end{array}$ & $\begin{array}{r}129 \\
97 \\
69\end{array}$ & $\begin{array}{l}120 \\
124 \\
127\end{array}$ & $\begin{array}{r}39 \\
114 \\
123\end{array}$ & $\begin{array}{r}48 \\
20 \\
217\end{array}$ & $\begin{array}{l}135 \\
197 \\
199\end{array}$ & $\begin{array}{l}102 \\
106 \\
149\end{array}$ \\
\hline & & Mean & 516 & 161 & 73 & 129 & 98 & 124 & 92 & 95 & 177 & 119 \\
\hline \multirow[t]{2}{*}{$\begin{array}{l}7 \\
8 \\
9\end{array}$} & $\begin{array}{l}\text { HCG† } \\
\text { HCG } \\
\text { HCG }\end{array}$ & & $\begin{array}{l}528 \\
820 \\
630\end{array}$ & $\begin{array}{r}95 \\
315 \\
118\end{array}$ & $\begin{array}{r}59 \\
160 \\
82\end{array}$ & $\begin{array}{r}59 \\
85 \\
0\end{array}$ & $\begin{array}{r}101 \\
79 \\
28\end{array}$ & $\begin{array}{r}128 \\
95 \\
85\end{array}$ & $\begin{array}{r}7 \\
0 \\
165\end{array}$ & $\begin{array}{r}82 \\
269 \\
212\end{array}$ & $\begin{array}{r}98 \\
307 \\
339\end{array}$ & $\begin{array}{r}79 \\
164 \\
129\end{array}$ \\
\hline & & Mean & 659 & 176 & 100 & 48 & 69 & 103 & 57 & 190 & 248 & 124 \\
\hline \multirow[t]{2}{*}{$\begin{array}{l}10 \\
11 \\
12\end{array}$} & $\begin{array}{l}\text { Estradiol + HCG } \\
\text { Estradiol + HCG } \\
\text { Estradiol + HCG }\end{array}$ & & $\begin{array}{l}467 \\
651 \\
628\end{array}$ & $\begin{array}{r}10 \\
231 \\
129\end{array}$ & $\begin{array}{r}153 \\
88 \\
104\end{array}$ & $\begin{array}{r}157 \\
94 \\
168\end{array}$ & $\begin{array}{l}186 \\
101 \\
107\end{array}$ & $\begin{array}{r}180 \\
94 \\
30\end{array}$ & $\begin{array}{l}420 \\
143 \\
351\end{array}$ & $\begin{array}{l}413 \\
198 \\
377\end{array}$ & $\begin{array}{l}412 \\
281 \\
422\end{array}$ & $\begin{array}{l}241 \\
154 \\
211\end{array}$ \\
\hline & & Mean & 582 & 123 & 115 & 140 & 131 & 101 & 305 & 329 & 372 & 202 \\
\hline
\end{tabular}

* Standard errors of mean values for three placentas of one treatment : 1) over 8 hours, 20.9 mg. per gland per hour; 2) at any one hour, $41.0 \mathrm{mg}$. per gland per hour.

† Human chorionic gonadotropin.

Table III was used. The significance of differences in hour to hour values was tested by the error term of line 7 of Table III. From these mean squares appropriate standard errors may be calculated. For citrate utilization and alpha-keto acid accumulation, respectively, the values are 36 and $1.14 \mathrm{mg}$. per hour for the standard error of the mean for a single placenta, 21 and $0.66 \mathrm{mg}$. per hour for the standard error of the mean for a group of three placentas, and 72 and $3.6 \mathrm{mg}$. for the standard error of a single hourly value.

Citrate utilization by the placenta was demonstrated during eight hours of perfusion with the standard solution. The values observed from hour to hour in the control group did not vary significantly $(p>0.20)$. The mean hourly utilization in this group was $107 \mathrm{mg}$. per gland. During perfusion with the standard perfusion fluid alpha-keto acid production was demonstrated. With each succeeding hour there was a highly significant $(p<0.01)$ tendency for less alpha-keto acid to be produced. During the sixth hour negative values were observed. The mean accumulation over the eight hours was $2.93 \mathrm{mg}$. per hour per gland.
When estradiol was added to the perfusion fluid there was no significant change in the amount or the pattern of citrate utilization during the eight hours of perfusion. The mean citrate utilization per hour per placenta was $119 \mathrm{mg}$. in the estradioltreated group of three placentas. The accumulation of alpha-keto acid in the estradiol-treated group was similar to the control group and showed a similar tendency to decrease with the passage of time. The mean accumulation was $3.45 \mathrm{mg}$. per hour per gland.

In the perfusions performed with added HCG, the mean citrate utilization was $124 \mathrm{mg}$. per hour per gland, not significantly different from that of the two previous treatment groups. However, in contrast to the more uniform pattern of citrate utilization in the control and estradiol-treated groups there were significant $(p<0.01)$ hour to hour variations in the HCG-treated group without any definite trend. The citrate utilization during the eighth hour of perfusion with fluid containing HCG showed significant increase over the corresponding value for the control group ( $p<0.05)$. The pattern of alpha-keto acid production in the gonadotropin group was similar to that of the 
TABLE II

Alpha-keto acid accumulation (mg. per gland) *

\begin{tabular}{|c|c|c|c|c|c|c|c|c|c|c|c|c|}
\hline \multirow{2}{*}{$\begin{array}{c}\text { Expt. } \\
\text { no. }\end{array}$} & \multirow[b]{2}{*}{ Treatment } & & \multirow{2}{*}{$\begin{array}{c}\text { Gland } \\
\text { weight } \\
\text { (grams) }\end{array}$} & \multicolumn{8}{|c|}{ Hour } & \multirow[b]{2}{*}{ Mean } \\
\hline & & & & 1 & 2 & 3 & 4 & 5 & 6 & 7 & 8 & \\
\hline \multirow[t]{2}{*}{$\begin{array}{l}1 \\
2 \\
3\end{array}$} & $\begin{array}{l}\text { Control } \\
\text { Control } \\
\text { Control }\end{array}$ & & $\begin{array}{l}639 \\
474 \\
579\end{array}$ & $\begin{array}{r}3.2 \\
5.6 \\
11.0\end{array}$ & $\begin{array}{l}5.4 \\
5.1 \\
6.5\end{array}$ & $\begin{array}{r}9.8 \\
11.9 \\
2.9\end{array}$ & $\begin{array}{l}8.6 \\
2.5 \\
1.5\end{array}$ & $\begin{array}{r}-0.9 \\
2.3 \\
1.6\end{array}$ & $\begin{array}{r}0.7 \\
-8.5 \\
-0.2\end{array}$ & $\begin{array}{r}-1.6 \\
1.1 \\
-2.2\end{array}$ & $\begin{array}{l}2.0 \\
0.2 \\
1.8\end{array}$ & $\begin{array}{l}3.4 \\
2.5 \\
2.9\end{array}$ \\
\hline & & Mean & 564 & 6.6 & 5.7 & 8.2 & 4.2 & 1.0 & -2.7 & -0.9 & 1.3 & 2.9 \\
\hline \multirow[t]{2}{*}{$\begin{array}{l}4 \\
5 \\
6\end{array}$} & $\begin{array}{l}\text { Estradiol } \\
\text { Estradiol } \\
\text { Estradiol }\end{array}$ & & $\begin{array}{l}514 \\
624 \\
410\end{array}$ & $\begin{array}{l}9.7 \\
8.8 \\
3.0\end{array}$ & $\begin{array}{r}15.5 \\
4.3 \\
2.3\end{array}$ & $\begin{array}{r}9.2 \\
13.2 \\
4.2\end{array}$ & $\begin{array}{r}-1.1 \\
3.0 \\
0.0\end{array}$ & $\begin{array}{r}-1.3 \\
-1.0 \\
0.8\end{array}$ & $\begin{array}{r}1.8 \\
-5.2 \\
-0.5\end{array}$ & $\begin{array}{l}3.2 \\
2.4 \\
1.3\end{array}$ & $\begin{array}{l}3.3 \\
0.9 \\
4.9\end{array}$ & $\begin{array}{l}5.0 \\
3.3 \\
2.0\end{array}$ \\
\hline & & Mean & 516 & 7.2 & 7.4 & 8.9 & 0.6 & -0.5 & -1.3 & 2.3 & 3.0 & 3.4 \\
\hline \multirow[t]{2}{*}{$\begin{array}{l}7 \\
8 \\
9\end{array}$} & $\begin{array}{l}\text { HCG } \\
\text { HCG } \\
\text { HCG }\end{array}$ & & $\begin{array}{l}528 \\
820 \\
630\end{array}$ & $\begin{array}{r}10.4 \\
4.3 \\
7.9\end{array}$ & $\begin{array}{l}9.3 \\
5.5 \\
8.5\end{array}$ & $\begin{array}{l}7.5 \\
6.9 \\
2.7\end{array}$ & $\begin{array}{l}5.1 \\
3.9 \\
2.0\end{array}$ & $\begin{array}{r}-0.4 \\
8.6 \\
-1.0\end{array}$ & $\begin{array}{r}-0.1 \\
-4.1 \\
0.8\end{array}$ & $\begin{array}{r}0.1 \\
-3.6 \\
4.6\end{array}$ & $\begin{array}{l}1.3 \\
1.2 \\
2.6\end{array}$ & $\begin{array}{l}4.1 \\
2.8 \\
3.5\end{array}$ \\
\hline & & Mean & 659 & 7.5 & 7.8 & 5.7 & 3.7 & 2.4 & -1.1 & 0.4 & 1.7 & 3.5 \\
\hline \multirow[t]{2}{*}{$\begin{array}{l}10 \\
11 \\
12\end{array}$} & $\begin{array}{l}\text { Estradiol + HCG } \\
\text { Estradiol + HCG } \\
\text { Estradiol + HCG }\end{array}$ & & $\begin{array}{l}467 \\
651 \\
628\end{array}$ & $\begin{array}{r}11.6 \\
-5.1 \\
3.6\end{array}$ & $\begin{array}{r}5.1 \\
-2.9 \\
7.0\end{array}$ & $\begin{array}{l}1.5 \\
2.1 \\
2.2\end{array}$ & $\begin{array}{r}1.1 \\
2.8 \\
-0.8\end{array}$ & $\begin{array}{l}2.6 \\
1.1 \\
9.1\end{array}$ & $\begin{array}{r}-4.9 \\
-2.8 \\
1.4\end{array}$ & $\begin{array}{r}-2.1 \\
4.0 \\
0.2\end{array}$ & $\begin{array}{r}-0.7 \\
1.1 \\
1.8\end{array}$ & $\begin{array}{l}1.8 \\
0.0 \\
3.1\end{array}$ \\
\hline & & Mean & 582 & 3.4 & 3.1 & 1.9 & 1.0 & 4.3 & -2.1 & 0.7 & 0.7 & 1.6 \\
\hline
\end{tabular}

* Standard errors of mean values for three placentas of one treatment: 1) over 8 hours, $0.66 \mathrm{mg}$. per gland per hour ; 2) at any one hour, $2.1 \mathrm{mg}$. per gland per hour.

previous groups. The mean of $3.50 \mathrm{mg}$. per hour per gland was not significantly different from the mean of the control or estradiol group.

Striking differences were obtained when placentas were perfused with fluid containing both estradiol and HCG. The mean citrate utilization was $202 \mathrm{mg}$. per hour per placenta, approximately twice the control value $(p<0.02)$. In addition, the hour to hour values revealed a significant regression on time $(p<0.001)$, with a marked increase in citrate utilization during the last three hours of perfusion. In the first five hours, there was no significant difference between any two groups at the same hour. Although the mean alpha-keto acid production was less in the combined treatment group (1.62 mg. per hour per glard) than in any other group, the difference was not significant. The observed hourly variation in alpha-keto acid accumulation was not significant.

A number of control experiments were performed to exclude the possibility of artifacts as the cause of the foregoing observations. To test whether citrate utilization and alpha-keto acid accumulation were the result of nonspecific changes in the perfusion fluid, $10 \mathrm{ml}$. aliquots of standard perfusing fluid which had been perfused through the placenta in the routine fashion were incubated in a shaking water bath at $37^{\circ} \mathrm{C}$. and in an

TABLE III

Analysis of variance

\begin{tabular}{|c|c|c|c|c|}
\hline \multirow[b]{2}{*}{ Line } & \multirow[b]{2}{*}{ Source of variation } & \multirow[b]{2}{*}{$\begin{array}{l}\text { Degrees } \\
\text { of } \\
\text { freedom }\end{array}$} & \multicolumn{2}{|c|}{ Mean squares } \\
\hline & & & Citrate & $\begin{array}{l}\text { Alpha- } \\
\text { keto } \\
\text { acid }\end{array}$ \\
\hline $\begin{array}{l}1 \\
2\end{array}$ & $\begin{array}{l}\text { Between placentas: } \\
\text { Between treatments } \\
\text { Within treatments } \\
\text { Hourly differences: } \dagger\end{array}$ & $\begin{array}{l}3 \\
8\end{array}$ & $\begin{array}{l}45,190^{*} \\
10,440\end{array}$ & $\begin{array}{l}18.2 \\
10.5\end{array}$ \\
\hline $\begin{array}{l}3 \\
4 \\
5\end{array}$ & $\begin{array}{l}\text { Control } \\
\text { Estradiol } \\
\text { Chorionic gonado- }\end{array}$ & $\begin{array}{l}7 \\
7\end{array}$ & $\begin{array}{l}1,040 \\
3,900\end{array}$ & $\begin{array}{l}44.0 \ddagger \\
45.5 \ddagger\end{array}$ \\
\hline $\begin{array}{l}6 \\
7\end{array}$ & $\begin{array}{l}\text { tropin } \\
\text { Combined hormones } \\
\text { Residual error }\end{array}$ & $\begin{array}{l}7 \\
7\end{array}$ & $\begin{array}{l}15,580 \ddagger \\
37,850 \$\end{array}$ & $\begin{array}{l}32.2^{*} \\
12.0\end{array}$ \\
\hline & within placentas & 56 & 5,220 & 13.1 \\
\hline
\end{tabular}

$* p<0.05$.

$\dagger$ The hourly differences in the various treatment groups were analyzed separately because, as is shown by lines 3 through 7 for the citrate values, the trends were very different from treatment to treatment. The alpha-keto values were given a similar analysis in the interests of consistency.

$\ddagger \mathrm{p}<0.01$.

$8 \mathrm{p}<0.001$. 
TABLE IV

Change in circulating potassium ( $m E q$. per gland) *

\begin{tabular}{|c|c|c|c|c|c|c|c|c|c|c|c|}
\hline \multirow{2}{*}{$\begin{array}{c}\text { Expt. } \\
\text { no. }\end{array}$} & \multirow[b]{2}{*}{ Treatment } & & \multicolumn{8}{|c|}{ Hour } & \multirow[b]{2}{*}{ Mean } \\
\hline & & & 1 & 2 & 3 & 4 & 5 & 6 & 7 & 8 & \\
\hline \multirow[t]{2}{*}{$\begin{array}{l}1 \\
2 \\
3\end{array}$} & $\begin{array}{l}\text { Control } \\
\text { Control } \\
\text { Control }\end{array}$ & & $\begin{array}{l}-0.07 \\
-0.84 \\
+1.28\end{array}$ & $\begin{array}{l}+0.55 \\
-0.96 \\
-0.17\end{array}$ & $\begin{array}{l}-0.46 \\
-0.05 \\
-0.69\end{array}$ & $\begin{array}{c}-0.04 \\
+0.19 \\
0.0\end{array}$ & $\begin{array}{l}-0.87 \\
-0.01 \\
-0.02\end{array}$ & $\begin{array}{l}+0.39 \\
+0.14 \\
+0.10\end{array}$ & $\begin{array}{l}-0.13 \\
+0.36 \\
+0.01\end{array}$ & $\begin{array}{l}+0.16 \\
-0.10 \\
+0.10\end{array}$ & $\begin{array}{l}-0.16 \\
-0.06 \\
+0.08\end{array}$ \\
\hline & & Mean & +0.12 & -0.19 & -0.40 & +0.05 & -0.30 & +0.21 & +0.08 & +0.05 & -0.05 \\
\hline \multirow[t]{2}{*}{$\begin{array}{l}10 \\
11 \\
12\end{array}$} & $\begin{array}{l}\text { Estradiol + HCG } \\
\text { Estradiol + HCG } \\
\text { Estradiol + HCG }\end{array}$ & & $\begin{array}{l}-0.53 \\
+1.16 \\
+0.50\end{array}$ & $\begin{array}{l}-1.06 \\
-0.39 \\
-0.06\end{array}$ & $\begin{array}{l}-0.27 \\
+0.10 \\
-0.46\end{array}$ & $\begin{array}{l}-1.10 \\
-0.37 \\
-0.07\end{array}$ & $\begin{array}{l}-0.35 \\
-0.07 \\
+0.24\end{array}$ & $\begin{array}{l}+0.25 \\
+0.08 \\
+0.08\end{array}$ & $\begin{array}{l}+0.48 \\
0.0 \\
+0.39\end{array}$ & $\begin{array}{l}+0.29 \\
-0.06 \\
+0.06\end{array}$ & $\begin{array}{l}-0.29 \\
+0.06 \\
+0.08\end{array}$ \\
\hline & & Mean & +0.37 & -0.50 & -0.21 & -0.51 & -0.06 & +0.14 & +0.29 & +0.10 & -0.05 \\
\hline
\end{tabular}

* Standard errors of mean values for three placentas of one treatment : 1) over 8 hours, 0.097 mEq. per gland per hour ; 2) at any one hour, $0.28 \mathrm{mEq}$. per gland per hour.

atmosphere of 100 per cent oxygen for 55 minutes. Under these conditions, the concentrations of citrate and alpha-keto acid in the perfusate showed no significant or consistent change in contrast to the changes already noted during the actual placental perfusion. The average hourly change in citrate concentration during the reincubation was +0.6 per cent with a range of -7 to +7 per cent. Similarly, the average hourly change in alphaketo acid concentration during the reincubation was -0.7 per cent.

As an index of cellular damage during perfusion the changes in circulating potassium concentration during each hourly run were recorded in six perfusions (Table IV). The potassium con-

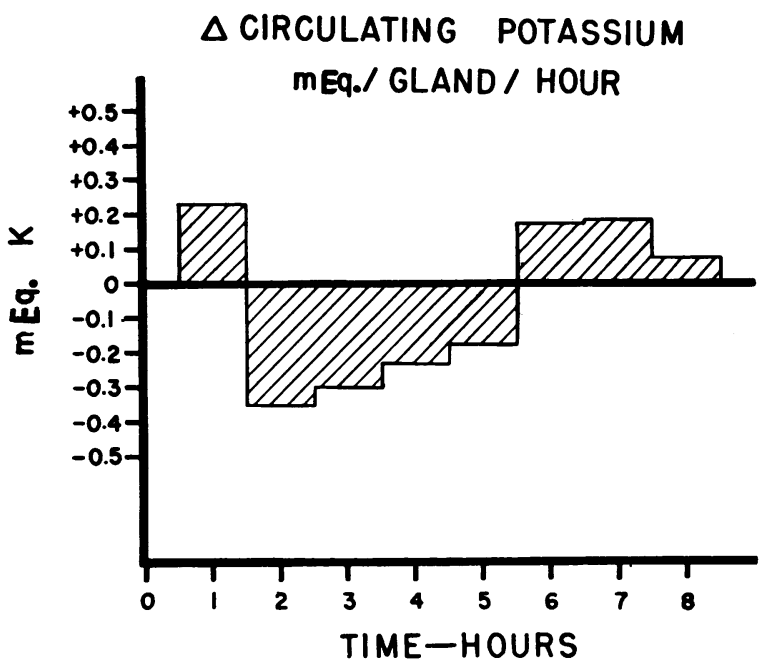

Fig. 3. Changes in Total Circulating Potassium during Each Hour of PERfusion

Each value is the average for six placental perfusions. centration in the perfusate was not affected by the presence or absence of hormones. In Figure 3 are depicted the average net hourly changes of circu-, lating potassium. In the first hour of perfusion the potassium concentration tended to increase, possibly due to hemolysis of blood retained in the placenta. During the next four hours of perfusion there was a small hourly decrease in perfusate. potassium followed by a slight hourly increase during the last hours.

Fluoroacetate ( $1 \mathrm{mM}$ per L.) was added to the perfusing fluid in three additional experiments (Table V). The mean values of citrate utilization were : $54 \mathrm{mg}$. for the placenta perfused with standard solution containing fluoroacetate, and 78 and $70 \mathrm{mg}$., respectively, for the two placentas perfused with standard solution containing estradiol, HCG and fluoroacetate. Using the error term of line 2, Table III, the difference between mean values observed among three placentas and one placenta, respectively, would have a standard error of $42 \mathrm{mg}$. The difference between mean values observed among three placentas and two placentas, respectively, would have a standard error of $33 \mathrm{mg}$. Thus, although the standard solution plus fluoroacetate-treated gland had one-half the citrate utilization of the corresponding group perfused without fluoroacetate, the difference was not significant $(p>0.10) .{ }^{5}$ However, in the

5 If the true effect of fluoroacetate is to reduce utilization of citrate by 50 per cent, it would be necessary to compare 10 control placentas with 10 placentas treated with fluoroacetate in order to have a 90 per cent probability of finding a significant difference at a level of $\mathrm{p}<0.05$. 
TABLE V

Effect of fluoroacetate on citrate utilization (mg. per gland)

\begin{tabular}{lccrrrrrrrrr}
\hline \hline $\begin{array}{c}\text { Expt. } \\
\text { no. }\end{array}$ & $\begin{array}{c}\text { Gland } \\
\text { weight } \\
\text { (grams) }\end{array}$ & Treatment & 1 & 2 & 3 & 4 & 5 & 6 & 7 & 8 & Mean \\
\hline 13 & Control plus & 804 & 28 & 14 & 13 & 155 & 59 & 53 & 98 & 9 & 54 \\
14 & $\begin{array}{c}\text { fluoroacetate } \\
\text { Estradiol HCG } \\
\text { fluoroacetate }\end{array}$ & 507 & 69 & -34 & 118 & 102 & 111 & 68 & 85 & 111 & 78 \\
15 & $\begin{array}{c}\text { Estradiol HCG } \\
\text { fluoroacetate }\end{array}$ & 585 & 40 & 91 & 62 & 134 & 11 & -24 & 127 & 120 & 70 \\
\hline
\end{tabular}

gland perfused with standard solution containing estradiol and HCG, the added fluoracetate completely blocked the stimulation of citrate utilization produced by these hormones $(p<0.001)$ (Figure 4). These p values are based on onesided $t$ tests.

The perfusate was cultured and showed no significant bacterial contamination.

\section{DISCUSSION}

These experiments demonstrate that placental metabolic activity is present for at least eight hours of perfusion of the intact gland and that this activity can be enhanced and inhibited. The response to added estradiol is not the same as noted in placental homogenates. A previously undescribed action of HCG is noted. This demonstration of a metabolically responsive gland under our conditions of perfusion establishes a firm basis for further study of the metabolic and endocrine functions of the placenta by this perfusion technique.

Fluoroacetate was used to afford additional evidence that the citrate disappearance was due to a metabolic process. Fluoroacetate, after conversion to fluorocitrate, inhibits the enzyme aconitase (22) and thus interrupts the Krebs cycle. The marked reduction of placental citrate utilization noted here in the presence of fluoroacetate indicates that such a metabolic pathway is indeed involved in the observed citrate disappearance. The failure of the added fluoroacetate to block citrate disappearance completely may have been due to failure to select an optimal concentration of fluoroacetate or to the fact that a small but constant disappearance of citrate was due to increasing volume of distribution during the hours of perfusion. The absence of significant weight gain by the placenta suggested that such minor distribution changes, if any, did not involve gross edema formation.
To provide an index of the degree of cellular damage and alteration in cell membrane permeability during the perfusion period, the circulating potassium concentration was determined. The relative constancy of the potassium concentration did not indicate any major shifts of potassium from the intracellular fluid. This suggested maintenance of cellular integrity during the perfusion. Moreover, failure to demonstrate changes in citrate and alpha-keto acid concentrations after reincubation of the perfused fluid indicated the absence of appropriate enzymes and cofactors for citrate metabolism in the extracellular fluid. This latter observation is in contrast to the findings of Levitz, Condon and Dancis (23) who demonstrated that after perfusion through an isolated cotyledon of human placenta, plasma gained the capacity to interconvert estradiol and estrone.

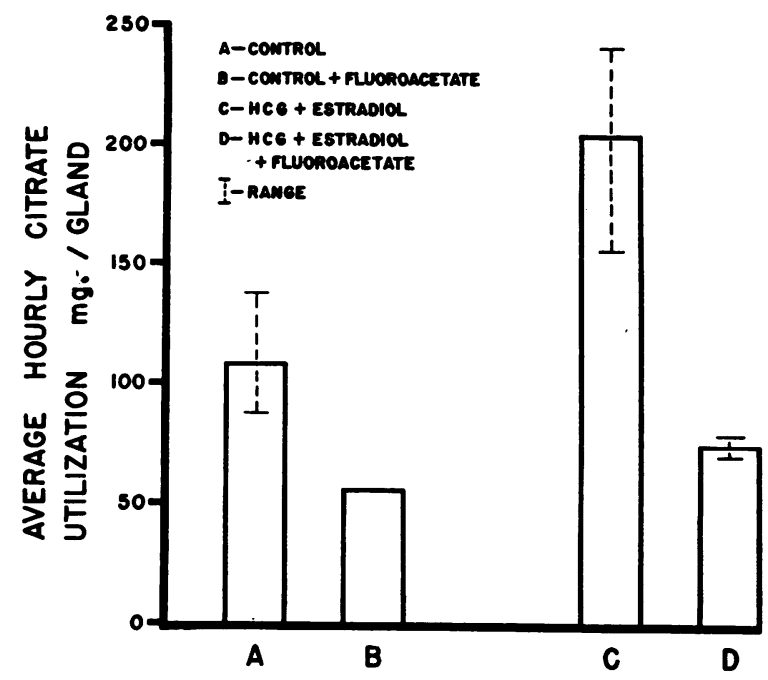

Fig. 4. The Effect of Sodium Fluoroacetate upon Citrate Utilization by Placentas Perfused with Standard Perfusing Solution ("Control") and with Added Estradiol and Human Chorionic GonadoTROPIN 
Villee and Gordon (24-27) have studied the effect of estradiol-17 $\beta$ on Krebs cycle activity of human placental tissue. In a particulate-free cytoplasmic preparation this estrogen effect was manifested by increased citrate utilization and alpha-ketoglutarate production. ${ }^{\circ}$ Such an estrogen effect was not demonstrated in the placenta perfusion system as here studied. Cellular permeability to estrogen may be a factor which is responsible for the discrepancy.

However, marked stimulation of citrate utilization occurred when both estradiol and HCG were added to the perfusing fluid. The ability of fluoroacetate to block completely this effect afforded confirmation that the response to hormones was a metabolic process. To a lesser degree the addition of HCG alone to the perfused placenta appeared to have an effect on citrate metabolism as judged by a significant increase of citrate utilization in the final hour of perfusion. These results are the first demonstration of such an action of HCG.

The mechanism of HCG action here is not known. A possible explanation may be that HCG increases permeability of the cell membrane to estrogen. Other loci of action of HCG might be in affecting estrogen interconversions or as a cofactor in the enzymatic reaction stimulated by estradiol. Studies on the effect of HCG on androgen secretion by the testis (29) suggest that HCG activates an enzyme system related to the biosynthesis of androgens.

Of interest is the definite lag period of five hours before the effect of combined estradiol and HCG was noted and the even longer lag period before the smaller effect of HCG alone took place. Recently Pincus reported on a several hour lag period for the effects of gonadotropin on steroidogenesis by the perfused placenta (30). The lag period would appear to be related to the mechanism of action of the hormones rather than to a nonspecific effect such as decrease of cellular integrity as the perfusion progresses. The data on circulating potassium concentration and perfusate reincubation appear to support the former hypothesis.

- Talalay and Williams-Ashman have recently shown (28) that the steroid activates a transhydrogenase system, thus leading to the effects noted.
In our studies, alpha-keto acid accumulation was not only relatively small, but also decreased with time and showed no increase even with increased citrate utilization. This discrepancy may in part be ascribed to the lack of actual identification of the measured alpha-keto acid as alpha-keto glutarate in this study. Another explanation is that in the intact placenta the metabolic conversions of alpha-keto glutarate to glutamic acid by the transaminase and glutamic acid dehydrogenase reactions and to succinic acid by oxidative decarboxylation may not be rate limiting. The persistence of these metabolic processes in the perfused gland would thus not allow an accumulation of alpha-keto glutarate proportional to citrate utilization as noted in purified placental homogenate. The decreasing alpha-keto acid accumulation of the perfused placenta despite much larger citrate utilization may, therefore, be further evidence of continuing and widespread metabolic activity.

\section{SUMMARY}

Perfusion of the intact human placenta was undertaken to provide data concerning endocrine functions of the placenta. The presence of citrate metabolism through the eight hour perfusion confirmed the viability of the placenta when studied in this fashion.

When human chorionic gonadotropin (HCG) plus estradiol-17 $\beta$ were added to the perfusion fluid citrate utilization was enhanced after a five hour lag period. The addition of HCG alone appeared to stimulate citrate utilization to a lesser degree and after a longer lag period. Estradiol alone had no effect. Citrate utilization was inhibited by the addition of fluoroacetate and the response to hormonal stimulation completely blocked.

The mechanism of action of this previously undescribed effect of HCG is not known.

The differences between metabolic processes of the intact placenta and purified preparations are discussed.

\section{ACKNOWLEDGMENT}

The authors express their sincere thanks to Dr. Harold Rosenfield and the members of his Obstetrical Staff at the Beth Israel Hospital for their cooperation in making available placentas for this study, and to Dr. Mindel Sheps of the Harvard School of Public Health for statistical analysis of the data. 
The authors express their appreciation for the loyal technical assistance given by Mrs. Margaret Proctor and Miss Frances Cochios.

\section{REFERENCES}

1. Lanman, J. T. Fetal-maternal endocrinology in late pregnancy in Transactions of the First Conference on Physiology of Prematurity. New York, Josiah Macy, Jr. Foundation, 1957, p. 11.

2. Jones, G. E. S., Gey, G. O., and Gey, M. K. Hormone production by placental cells maintained in continuous culture. Bull. Johns Hopk. Hosp. 1943, $72,26$.

3. Stewart, H. L., Jr. Hormone secretion by human placenta grown in the eyes of rabbits. Amer. J. Obstet. Gynec. 1951, 61, 990.

4. Solomon, S., Lenz, A. L., Vandewiele, R., and Lieberman, S. Pregnenolone, an intermediate in the biosynthesis of progesterone and the adrenocortical hormones. Presented at the 126th meeting of Amer. Chem. Soc. 1954, New York, N. Y.

5. Johnson, R. H., and Haines, W. J. Extraction of adrenal cortex hormone activity from placental tissue. Science 1952, 116, 456.

6. De Courcy, C., Gray, C. H., and Lunnon, J. B. Adrenal cortical hormones in human placenta. Nature (Lond.) 1952, 170, 494.

7. Jailer, J. W., and Knowlton, A. I. Simulated adrenocortical activity during pregnancy in an Addisonian patient. J. clin. Invest. 1950, 29, 1430.

8. Opsahl, J. C., and Long, C. N. H. Identification of ACTH in human placental tissue. Yale J. Biol. Med. 1951, 24, 199.

9. Sulman, F. G., and Bergmann, R. Adrenocorticotrophic activity of placental extracts. J. Obstet. Gynaec. Brit. Emp. 1953, 60, 123.

10. Damiani, N., and Cagnazzo, G. Determination of 17-ketosteroids in the human placenta after testosterone propionate deficiency. Quad. Clin. ostet. ginec. 1952, 7, 25.

11. Zarrow, M. X., Holmstrom, E. G., and Salhanick, H. A. The concentration of relaxin in the blood serum and other tissues of women during pregnancy. J. clin. Endocr. 1955, 15, 22.

12. Berliner, D. L., Jones, J. E., and Salhanick, H. A. The isolation of adrenal-like steroids from the human placenta. J. biol. Chem. 1956, 223, 1043.

13. Hechter, O., Zaffaroni, A., Jacobsen, R. P., Levy, H., Jeanloz, R. W., Schenker, V., and Pincus, G. The nature and the biogenesis of the adrenal secretory product. Rec. Progr. Hormone Res. 1951, 6, 215.

14. Wislocki, G. B., and Bennett, H. S. The histology and cytology of the human and monkey placenta, with special reference to the trophoblast. Amer. J. Anat. 1943, 73, 335.
15. Hellman, L. M., Harris, B. A., Jr., and Andrews, M. C. Studies of the metabolism of the human placenta. II. Oxygen consumption and anaerobic glycolysis in relation to aging and severe toxemia. Bull. Johns Hopk. Hosp. 1950, 87, 203.

16. Villee, C. A., and Hagerman, D. D. Effects of estradiol on the metabolism of human placenta in vitro. J. biol. Chem. 1953, 205, 873.

17. Young, M. K., Jr., Prudden, J. F., and Stirman, J. A. A perfusion technique for the study of liver metabolism. J. Lab. clin. Med. 1955, 46, 155.

18. Natelson, S., Pincus, J. B., and Lugovoy, J. K. Microestimation of citric acid: A new colorimetric reaction for pentabromoacetone. J. biol. Chem. $1948,175,745$

19. Friedemann, T. E., and Haugen, G. E. Pyruvic acid. II. The determination of keto acids in blood and urine. J. biol. Chem. 1943, 147, 415.

20. Snedecor, G. W. Statistical Methods. Ames, Iowa State College Press, 1956, p. 285.

21. Cochran, W. G., and Cox, G. M. Experimental Designs. New York, John Wiley and Sons, 1950, p. 218.

22. Peters, R., Wakelin, R. W., Buffa, P., and Thomas, L. C. Biochemistry of fluoroacetate poisoning. The isolation and some properties of the fluorotricarboxylic acid inhibitor of citrate metabolism. Proc. roy. Soc. B 1953, 140, 497.

23. Levitz, M., Condon, G. P., and Dancis, J. The interconversion of estrone and estradiol in the perfused human placenta. Endocrinology 1956, 58, 376.

24. Villee, C. A. An estradiol-induced stimulation of citrate utilization by placenta. J. biol. Chem. 1955, 215, 171.

25. Villee, C. A., and Gordon, E. E. Further studies on the action of estradiol in vitro. J. biol. Chem. 1955, 216, 203.

26. Gordon, E. E., and Villee, C. A. Spectrophotometric studies of the stimulation of human placental preparations by estradiol. J. biol. Chem. 1955, 216, 215.

27. Gordon, E. E., and Villee, C. A. An in vitro assay for estradiol-17 $\beta$ and estrone. Endocrinology 1956, 58,150 .

28. Talalay, P., and Williams-Ashman, H. G. Activation of hydrogen transfer between pyridine nucleotides by steroid hormones. Proc. nat. Acad. Sci. (Wash.) 1958, 44, 15.

29. Brinck-Johnsen, T., and Eik-Nes, K. Effect of human chorionic gonadotropin on the secretion of testosterone and 4-androstene-3, 17-dione by the canine testis. Endocrinology 1957, 61, 676.

30. Pincus, G. Steroidogenesis in perfused human placentas in Transactions of the Third Conference on Gestation. New York, Josiah Macy, Jr. Foundation, 1957, p. 91. 